\title{
Review on Perception and Adaptation Strategies of Smallholder Farmers' to Climate Change in Ethiopia
}

\author{
Tilahun Kenea ${ }^{1^{*}}$ Saron Mebratu ${ }^{2}$ \\ 1.Department of Agribusiness and Value Chain Management, College of Agriculture and Forestry, Mettu \\ University, P.O.Box 318, Bedele, Ethiopia \\ 2. Department of Agribusiness and Value Chain Management, Wolkite University, P.O.Box 07, Wolkite, \\ Ethiopia
}

\begin{abstract}
Ethiopian Smallholder farmers is highly vulnerable to climate variability and change due to its great reliance on climate sensetive economy.Different empirical evidence's has put forward about climate change perception and adaptation practices.However, the findings of major studies are highly aggregated and are of little help in addressing local peculiarities of perception and adaptation strategies. While, others were vague to understandand and finally difficult to implement at farm level. Hence ,this paper reviews the empirical literature on smallholder farmers' perceptions and adaptation strategies of climate change in Ethiopia with specific objectives of; to review the Smallholder framers' perception to climate change, to identify climate change adaptation strategies used by Smallholder farmers' and to review factors that determine smallholder farmers choice of climate change adaptation strategies in Ethiopia.This paper was prepared through wide spread review of empirical evidence's. The review found that the majority of farmers in Ethiopia are aware of climate change in average change in temperatures and rainfall pattern with passion of weather extremes such as droughts ,floods,pest and disease manifestation. To deal with up the unfavorable sound effects of climate change, farmers have adopted strategies like crop diversification, using improved varieties, changing planting and harvesting dates, irrigation, planting tree crops, water and soil conservation techniques,switching to non-farm income activities, marketing during forage shock, using drought tolerant breed andfodder preservation.But, preference of adaptation strategies differs from place to place, farms to farms, and households capacity. At household level, most of the empirical evidence revealed Agro-ecological setting, sex, education level, landholding, farm income, non-farm income, livestock ownership, access to credit, extension visit, farmer-to-farmer extension, access to climate information and average distance from home to the farm have significant influence on the choice of climate adaptation strategies. The review result depicted that there is much dearth of empirical evidences regarding livestock sectors so far as much of the research is focused on crop sector's. Therefore, it has been suggested to further investigate deep rooted emperical evidence's on adaptation strategies of livestock sectors and available indigenous knowledge especially in pastoral areas.Further more, there is a need to explore impacts of climate change and single adaptation strategies on livelihood of smallholder's farmers at each farm level autonomously.
\end{abstract}

Keywords: adaptation strategies; climate change; Ethiopia, perceptions; Smallholder farmer's

DOI: $10.7176 / \mathrm{IAGS} / 82-03$

Publication date:May $31^{\text {st }} 2020$

\section{INTRODUCTION}

\subsection{Background}

Climate change is one of the challenges to environment-human security and poses agreat threat to the livelihood of people who rely more in the agriculture sector in the world(Tesfahunegn et al., 2016, Gedefaw et al., 2018). Moreover, In Sub Saharan Africa, where smallholder farmers dominate the agriculture sector and are most vulnerable to adverse effects of climate change, it continues to strongly shock agriculture (Juana et al., 2013, Seid and Tamiru, 2015). From Sub Saharan Africa(SSA), Ethiopia is the most vurnelable country due to its high dependence on climate sensitive economy (Asrat and Simane, 2018).

Actually, "impact of climate variability and change are not new Scenario in history of Ethiopian and the three major famines periods of 1950,1960 and 1980s are the result of severe drought that is part of climate change " (Fikadu et al. 2015).The frequency of hot days, and much larger increasing trends in the frequency of hot nights ((Berhanu, 2001, NMS, 2007,ACCCA, 2010, Feleke et al., 2016). Furthermore, mean annual temperature of Ethiopia has already increased by $1.3^{\circ} \mathrm{C}$ between 1960 and 2006, and projected to increase by 1.1 to $3.1^{\circ} \mathrm{C}$ by the $2060 \mathrm{~s}$, and 1.5 to $5.1^{\circ} \mathrm{C}$ by the 2090s. While rainfall, is expected to show some increment between 0.6 and $4.9 \%$ and 1.1 to $18.2 \%$ for 2030 and 2050, respectively (NMA, 2006b, Weldlul 2016, REIT, 2017).

Unfortunately," these temperature and rainfall variation are forecasted to slow down growth of economy, increases severity of poverty,leads to food insecurity, and prolong existing and make new poverty gaps"(Gillis, 2014). And also, output of agriculture in Ethiopia expected to decline by $37 \%$ by 2050 unless remedial measures are taken into consideration (IPCC, 2012).Therefore, it is necessary to understand climate change challenges especially amongst smallholder farmers since agriculture is an essential component of their means of living. For 
these agricultural dependent vulnerable groups, even small variation in climate can have harmful impacts on their livelihood.

Agriculture is a very paramount sector in Ethiopian economy which accounted for $34.9 \%, 90 \%, 70 \%$ and $85 \%$; of the GDP, total export revenue, raw material requirement and labor force of country's respectively. Crop production accounts for $65.3 \%$ from the total agricultural share comprising 65.3 percent, followed by animal farming \& hunting (25.6 percent) and forestry (8.8 percent)(NBE, 2018).

In Ethiopia, climate change attributes like that of drought, land degradation, pests infestation and diseases manifestation are among the major factors responsible for the low agricultural production and productivity(Yirga, 2007, Asrat and Simane, 2018).Climate change possibly will affects the agricultural sectors of diverse countries in dissimilar ways, what is understandable is that these changes will convey about considerable wellbeing losses, particularly for smallholders whose key basis of living derives from agriculture(Komba and Muchapondw, 2015). The fact that climate change will adversely affect agriculture in the region has become a challenge for sustainable development on the continent(Juana et al., 2013).

By and large, victims in the agriculture segment because of climate change have economy wide price, akin to the turn down in Gross domestic product, led to loss of income and food deficit; thus, a general weakening in households' living standard (Seid and Tamiru, 2016 ). To reduce themselves against possible wellbeing losses, smallholder farmers require to be familiar with the changes already going on in their climate and embark on fitting measure(Komba and Muchapondw, 2015).

Accordingly, similar to any other third world countries, Ethiopia has two autonomous options to respond ; climate change mitigation and adaptation"(Seid and Tamiru, 2016 ). Given the low level of manufacturing sector, alleviation would not outfit to Ethiopia for it deters the growth spurs that has registered in the last few years. as an option, implementation of adaptation measures such as use of different crop varieties, agro forestry, soil and water conservation,adjusting planting date, and use of irrigation should be in use by farmers to conquer with climate change (Temsgen, 2014). This can be achieved by the smallholder Farmer's themselves taking adaptive actions or by governments implementing policies aimed at promoting appropriate and effective adaptation measures.

\subsection{Statement of the problem}

Various studies have been conducted in Ethiopia to assess climate change perceptions, adaptation strategies and determining factors. Though educational, the result of these investigations are highly aggregated and are of little help in addressing local peculiarities of perception and adaptation to climate change. This is due to some type of study consider adaptation practices in a relative manner without going into much aspect where as Some other discuss particular aspects of farmers' adaptation to climate change ,also vague to understand and finally difficult to implement at farm level, even if, the study was educational. Moreover, the existing studies have concluded that different regions have poles apart exposures to the risks of climate change. However, in order to expertise appropriate policy a response, as the susceptibility and sensitivity of each region differs, as does the accessibility of the different adaptation methods. Hence formulating suitable advice for implementing adaptation practice is not easy. In order to implement appropriate measure, it require concerned body(governments) understanding of the opportunities for adaptation and the key drivers behind voluntary adaptation by susceptible smallholder farmers(Fussel, 2007). Therefore, there is a call for blend these different studies and review against differences in climate change perceptions and adaptation in Ethiopia.

\subsection{Objective of the Seminar}

\subsubsection{General Objective}

To review Perception and Adaptation Strategies of Smallholder farmers' to Climate Change in Ethiopia.

\subsubsection{Specific Objectives}

$\checkmark$ To review Smallholder framers' perception to climate change in Ethiopia,

$\checkmark \quad$ To identify climate change adaptation strategies used by smallholder farmers of Ethiopia to conquer with adverse conditions of climate change,

$\checkmark$ To review factors that determine Smallholders farmers choice of climate change adaptation strategies in Ethiopia.

\subsection{Significance of the seminar}

This seminar takes stock of the burgeoning literature, and reviews evidences. Therefore, it was very important to the researchers and academicians involved in climate related exploring activities. Scientific publications that were produced from the study were used as vital instruments to initiate academic discourse between the research and academic community including students of higher learning institutions. It was also utmost importance to document and upgrade indigenous knowledge through scientific research of this kind and disseminate or transfer the knowledge and skill gained to all stakeholders within and outside the country. Moreever the review result prepare policy makers with necessary information for appropriate legislation regarding climate change. Furthermore, it 
can also provide input to efforts to formulate programs and activities that could accelerate adaptation strategies at household and community level.

\section{BODY OF THE LITERATURE REVIEW}

\subsection{Climate change and variability in Ethiopia}

Climate change is a change of climate which is contributed either directly or indirectly to humanbeing activity,as a result of human activities or naturally variability (UNFCCC, 2011, IPCC, 2013, ADB, 2015, WWF, 2015). "It changes the global and regional compositions of atmosphere and climate variability.Types of climate variability includes rainfall,occurrence of extremes and temperatures.In addition the climate change that causes the hazards on the area of socities health, agriculture, food security, forest and water resources, coastal area, biodiversity, settlement of human beings, energy, industry, and financial services" (UNFCCC, 2011, Gezie, 2019).

In Ethiopia, climate variability and change is highly observed through the variability and decreasing and increasing trend of rainfall and temperature respectively.Despite, rainfall and temperature patterns indicate large regional differences also, multitude of adverse effects of climate change are manifested including shortening or lengthen of maturity period and decrease in crop yield, decline in fodder and feed, lack of animal health,manifestation of diseases such as malaria, "reduction of pastoral zones in many parts of the country, expansion of tropical dry forests, increase of desertification, flood and drought impacts" (UNFCCC, 2011, Gezie, 2019).

In addition, a study conducted by (Seid et al., 2016)in western Ethiopia showed that the average annual temperature increases by average $0.0960 \mathrm{C}$ each year. The similar study confirmed that the total amount of annual rainfall in the study area decreases by about $46.75 \mathrm{~mm}$ each year.Climate change is acritical issue to current Ethiopia and important to be tackled in a state of emergency. It has caused $t$ an escalating risk to already existingl concerns of the countries environment including deforestation and agriculture sector" (NMA, 2006, Weldlul 2016). Generally, Ethiopia is highly susceptible to climate change hazards as it is principally a country followed agricultural development led industrialization policy and agriculture is harshly impacted by the changing climate. There is a solemn call for for contriving ways to adapting to the changing climate. "However, adaptation to climate change or variability seems to be delayed by lack of sufficient and timely information on climatic data as well as provision of technological packages"(Weldlul 2016). Therefore, the existence of functional institutional arrangements for climate change is critical for understanding and enhanced informing policies/measures for enhanced resilience to climate change. Ethiopia being determined to combat climate change has suitably reacted by passing pertinent international conventions and the necessary steps are being taken to implement the two categories of responses to climate change, mitigation and adaptation.

\subsection{Past and Future Scenario of Climate and Impacts in Ethiopia}

\subsubsection{Past Scenario of Climate and Its Impact in Ethiopia}

The climate of Ethiopian is described by incident's of climate extremes, such as drought and flood, and rising temperature and declining precipitation and irregular patterns. The history of climate extremes, especially drought, is not a new phenomenon in Ethiopia(NMSA, 2007, Lautze et al., 2013) .The country had suffered seven major droughts since the early 1970s and five of the droughts compounded by a number of local droughts had led to severe food insecurity and devastating famine (WBG, 2010). Though drought is already known issue in Ethiopia, its occurrence frequency has shown increments in some areas and likewise the variability in rainfall patterns (Weldleul 2016).

On an aggregate level, Ethiopia's economy will remain highly vulnerable to exogenous shocks, mainly because of its dependence on primary commodities and rain fed small-scale and subsistence-oriented agriculture.

Differnt Studies indicated that temperature and precipitation have been changing over time. Accordingly, minimum temperature has been increasing by about $0.3 \mathrm{oc}$ in every decade in the previous fifty five years. The average annual rainfall of the Ethiopia has recently indicated ahigh level of climate variability (NMS, 2007).In previous half decades a few years were characterized by dry conditions, resulting in drought and famine, whereas others are characterized by wet conditions. Droughts do not only reduce agricultural production, but also result in starvation, death, and foreign aid dependence. Droughts are among the reason for large dependence on food aid in Ethiopia. 
Table 1.Chronology of the effect of drought and famine on Ethiopia, 1964-2019

\begin{tabular}{|l|l|l|}
\hline Name ofimpacted regions & year of happening & Affected people number \\
\hline Tigray and wello & $1964-1966$ & 1.5 million people are harmed \\
\hline Tigray and welllo & $1972-1973$ & 200000 people and 30\% of livestocks are passed away \\
\hline Southern, Ethiopia & $1978-1979$ & About 1.4 million people are harmed \\
\hline All regions & $1983-1984$ & About 8 million people areharmed \\
\hline All regions & $1983-1988$ & About 7 million \\
\hline Northern, Ethiopia & 1992 & About 500,000 million peoples are harmed \\
\hline Tigray and wello & $1993-1994$ & About 7.6 million people are harmed \\
\hline All regions & 2000 & 10.5 million people are affected \\
\hline All regions & $2002-2003$ & 13 million people are harmed \\
\hline All regions & $2008-2009$ & 5 million people are harmed \\
\hline Eastern and northern region & $2015-2019$ & 10 million people are faced hunger \\
\hline
\end{tabular}

Source:(Degefu, 1987, Weldlul 2016,FAO,2019).

Recently, (2018/19) Ethiopia is facing the brunt of drought due to El Nino effect in the northern and eastern regions. As a result,over ten million people are relay on food aid. And, the overall scenario indicates that the country faces a complex problem associated with climate change and the drought causes. This year, (2018/2019), can be taken as a serious signal that puts heavy pressure on the government of Ethiopia to rethink about the problem and design a national drought management strategy to find a lasting solution for the recurring drought and climate change challenges(FAO, 2019). In this regard in its analysis of climate change and food security strongly advocated the need for investing in systems to assess risks, vulnerabilities and adaptation options and also strengthening adaptation through policies and institutions.

\subsubsection{Future Climate Change over Ethiopia}

According to the results of "IPCC mid-range emission scenario, the 1961-1990s the average mean annual temperature across Ethiopia will be expected to increase by between 0.9 and $1.1^{\circ} \mathrm{C}$ by the year 2030 and from 1.7 to $2.1^{\circ} \mathrm{C}$ by the year 2050 and in average range of 2.7 to $3.4^{\circ} \mathrm{C}$ by the year 2080 over Ethiopia, Where as the rainfall is expected to increase (NMA,2006). The results of the IPCC mid-range emission scenario indicated that there will be an alter of precipitation between 0.6 and 4.9 percent and $1.1-18.2$ percent for the year 2030 and 2050, accordingly. An small amount increase in annual rainfall is expected over the country, and other empirical evidence have also witnessed the climate variability and its trends in a more or less similar ways"(NMA, 2006, Weldlul 2016).

Ethiopia is in general vulnerable to climatic variability due to its low adaptive capacity that is principally associated with the low level of socioeconomic development, high population growth, low infrastructure, weak institutional performance and great reliance on natural resource-based activities(NMA, 2007, Weldlul 2016)."The vulnerability of the community is aggravated due to the long standing environmental problems of forest destruction that leads to land degradation.Further more, about $70 \%$ of the country is dry, sub-humid, semi-arid or arid and in consequence vulnerable to desertification and environmental degradation"(Weldlul 2016).

Generally; Many studies have estimated the future climate and investigated how this influences vulnerability"(Baca et al., 2014, Bouroncle et al., 2017) .However, fewer attempts have been made to also project the future societal adaptive capacity, as indicators are often difficult to estimate and uncertain" (Adger et al., 2004, Sherbinin et al., 2014. Similarly,levels of uncertainty hinder confidence in the estimations of natural exposure)which are unstable and chaotic by nature (Guzzetti, 2016).

\subsection{Agriculture and smallholders farmers in face of climate change in Ethiopia}

Agriculture is the most important sector in sub-Saharan Africa including Ethiopia, but it is predicted to be negatively impacted by climate change. Due to their socio-economic position, smallholder farmers are among the most disadvantaged and vulnerable groups affected by climate change and variability(IFPRI, 2007, ASFG, 2013) . Therefore, "the impact of climate change and variability threatens and weakens the already susceptible smallholder farmers whose major source of livelihood is rain fed agriculture. It is clear that climate change will carry about substantial welfare losses especially for smallholders whose main source of livelihood derives from agriculture" (Asrat and Simane, 2018c, Gezie, 2019) .

Smallholder farmers plays a crucial role in ensuring food security in Ethiopia. Most of farms are occupied by smallholder farmers (AGRA, 2014, Schaffnit-Chatterjee, 2014, Phiiri et al., 2016).However low technology adoption and lack of credit access make the life of smallholder farmer's in difficulty.

\subsection{Perception of climate change by Smallholder farmers of Ethiopia}

Smallholders' farmers in Ethiopia have been and are living in agreement with climate change.Many scholars has 
confirmed the information about climate change is a pre-condition for adapting to its adverse effects.Different empirical findings were investigated to digout farmersclimate change awareness status.

Bryan et al. (2009) investigated adaptation to climate change in Ethiopia and South Africa.The study revealed that farmer's perceived change in rainfall and temperature pattern in both countries.

Afinding by Gutu et al. (2012) Investigated local level perception, adaptation and coping strategies to climate change induced shocks in North Shewa, Ethiopi.The study employed Heckman two stage model ,revealed that "Perception to climate change decide adaptation strategy situations..

According to Belaineh et al. (2013b),awareness of climate variability and change are varied between gender and different social groups.

Fikadu et al. (2015) Analyzed Agents' perception about the effect of climate risk on livestock production. The study result depicted experts have awarded that climate change has affected smallholder farmers and livestock herders. Though informative, the study was restricted to livestock production and experts' perceptions of climate change risks.

According to Nega et al. (2015) study on perception of climate change and its impact by smallholders in pastoral/agro pastoral systems of Borana, South Ethiopia ,farmer's have aware the climate change is there and its negative impact on agriculture and Overall economy of the country.in addition this study depicted Age, education level, livestock holding, access to climate information and extension services significantly affected awareness levels.

Solomon et al. (2016) was investigated perception and adaptation models of climate change by the rural people of Lake Tana Sub-basin.From Heckman probit and multinomial logit revealed that marital status, farm size, climate change information access and the level of income generation play a crucial role in perception to climate change.

Wondimagegn and Lemma (2016) stududied on climate change perception and choice of adaptation strategie : using empirical evidence's from smallholder farmers in east Ethiopia.The study revealed that , majority of farmers in the study area are familiarized of climate change patterns and its impacts on livelihood of smallholder's farmers.

Weldlul (2016) study on Analysis of Smallholder Farmers' Perceptions of Climate Change and Adaptation Strategies to Climate Change: The Case of Western Amhara RegionThe result from descriptive statistics and multinomial logit mode depicted that about $87.3 \%$ noticed climatic change and their perception of climatic variable attributes.

Abrham et al. (2017) also investigated smallholder farmers ${ }^{e e}$ adaptation to climate change and determinants of their adaptation decisions in the Central Rift Valley of Ethiopia. The end result from descriptive statistics and multinomial logit model revealed that most of the farmers have perceived climate change and attempted to adap climate change.

Bewuketu (2017) also investigates Farmers' Perception and Adaptation Strategies to Climate Change: The Case of Woreillu District of Amhara Region, Northeastern Ethiopia using descriptive statistics and Likert scale and multivariate model. The descriptive statistics result showed that $87.74 \%$ and $83.22 \%$ of the respondents perceived the existence of climate change with its attributes, temperature and rainfall, respectively.

Gedefa et al. (2018) Study on Farmer's Perceptions and Adaptation Strategies to Climate Change, Its Determinants and Impacts in Ethiopia: Evidence from Qwara District using a descriptive statistics and logistic regression analysis revealed that $90 \%$ of the respondents responded that there is a change in climate parameters overtime. Climatic variability was perceived an increasing rate. The farmers also told that previously drought was occurred within ten years' interval but now it is observing at a frequency of less than five years. Asrat and Simane (2018) also assessed farmers' perception of climate change, local indicators of climate change and types of adaptation measures exercised to cop up with the risk of the change in climate. The result showed that farmers in the study area perceive the change in climate patterns and have devised a means to survive through implementing different adaptation strategies.

\subsection{Smallholders farmers' Adaptation Strategies to Climate Change in Ethiopia}

Farmers have been in responding to climate variability and change. Different adaptation practices can help farmers to deal with with both current climate variability and future climate change(Below et al., 2010). The debates about the arrangement of smallholder farmers in Ethiopia to climate change has occurred in the absence of community's knowledge about existing and latent adaptation practices. As a result, prevailing facts about adaptation are vague, conducting focused research on possible adaptation practices and formulating appropriate advice for implementing new practices is very tough tasks.

To adapt to climate change in Ethiopia, pastoral communities employed dug more boreholes in drier areas, shift to non-farm activities and destocking livestock, by slaughtering and selling them at time of extended drought periods,fodder preservation and restocking after the drought(Aemro et al., 2012a, Belaineh et al., 2013b, Aschalew, 2014, Abid et al., 2015, Gebru et al., 2015, Weldlul 2016, Wondimagegn and Lemma, 2016, Abrham et al., 2017 , Bewuketu, 2017, Asrat and Simane, 2018b, Bedeke et al., 2018, Gezie, 2019).While ,some livestock herders have 
shifted to livestock that resist water stress and hot temperatures like, camels and goats ((Belaineh et al., 2013b, Feleke et al., 2016).

Also,some other investigation depicted that houshold who have many family size will be more interested to prefer the coping and adaptation mechanism such as soil conservation techniques, chemical treatments that are labor intensive to implemted(Deressa et al., 2008, Aymone, 2009).

Moreover, ACCCA (2010) studied on analyses of adaptation strategy of farm households in Tigray ,Ethiopia using multivariate probit model.The study depicted that soil and water conservation practices,adjusting planting date,fertilizer usage, access to credit,and diversifies of crops are the most common adaptation strategy taken by farm households.

Belaineh et al. (2013b)examined smallholder farmer's perceptions and adaptation to climate variability and climate change in Doba District, West Hararghe Ethiopia using multinomial logit model.The finding showed that diversification of crops soil and water conservatio,shift to non farm activities,and irrigation using rain water conservation are major adaptation strategies employed in the study area.while livestock herders are practices adaptation stratetgy like marketing during forage shock and fodder preservations.

A research done by Gebru et al. (2015 )on farmers ${ }^{\text {ee }}$ climate change adaptation options and their determinants in Tigray Region, North Ethiopia.The result from the study employed descriptive statistics and multinomial logit model revealed that farmers use change in crop type or crop variety,soil and water conservation practices(SWC), diversificatio of crop varieties ,adjusting planting date and use of irrigation are most common adaptation strategy in the area.

Also, Wondimagegn and Lemma (2016) conducted a study on climate change perception and choice of adaptation strategie : empirical evidence from smallholder farmers in east Ethiopia. The multivariate probit model result revealed that the adjusting planting date ,cultivating different crops, planting different crop varieties, use of SWC practices,andshift to non-farm income activities are major adaptation strategies to change in climate in the study area.

Asrat and Simane (2018b) assessed farmers' perception of climate change, local indicators of climate change and types of adaptation measures exercised to cop up with the risk of the change in climate using Heckman samples selection model. The result from the study showed that implementing different adaptation strategies like use of improved crop varieties, agro forestry practices, soil conservation practices, irrigation practices, and adjusting planting dates are the most important adaptation strategies by smallholder farmers. However, adaptation decision is location-specific and influenced by key drivers such as socioeconomic, environmental, and institutional factors.

In general : Smallholder farmers in Ethiopia are struggling to climate change by using adaptation strategies such as diversification of crops,changing planting date and harvesting dates,irrigation, planting tree crops, increased use of water and soil conservation practices(SWC), and shifting to off-farm activities, where as that of livestock herders employed adaptation strategies like, livestock slaughtering and selling them during extended drought periods, fodder preservation and restocking after the drought, switched to camel and goats rearing because of their habit of drought tolerance and Withstanding of water stress, and dug more boreholes in drought areas.

2.6.Factors that determine Smallholder farmers Choice of climate change adaptation strategies in Ethiopia Different empirical findings innate that different demographic factors (such as gender, age of farmers, years of farming experience, household size and years of education) as well as institutional factors (such as access to credit and extension services and non farmincome generating activities) were identified as significant determinants of climate change adaptation strategies (Kurukulasuriya and Mendelson, 2006, Maddison, 2006, Deressa et al., 2008, Mertz et al., 2009, Fosu-Mensah et al., 2010, Acquah-de Graft and Onumah, 2011, Mandleni and Anim, 2011, Badege et al., 2013, Abid et al., 2015, Weldlul 2016, Abrham et al., 2017, Bewuketu, 2017, Asrat and Simane, 2018a).

(Aemro et al., 2012b) investigated climate change adaptation strategies of smallholder farmers in Babilie District, East Harerghe Zone of Oromia Regional State of Ethiopia. The outcome of multinomial logit model analysis showed that sex, age, and education of the household head; family size, livestock ownership, household farm income, non farm income, access to credit, distance to the nearest market, access to farmer-to-farmer extension, agro-ecological zones, access to climate information, and extension contact found to have a significant impact on climate change adaptation strategies.

According to Temesgen(2014) study on climate change adaptations of smallholder farmers in Southeast Ethiopia using descriptive statistics and multinomial logit model depicted that education, access to climate information, access to credit and farm income are signifcantly affected adaptation strategy like that of using agronomic practices and agricultural inputs

A research done by Gebru et al. (2015) on farmerse climate change adaptation options and their determinants in Tigray Region, North Ethiopia using descriptive statistics and multinomial logit model revealed that farmers, educational level, age, sex of the household head; farm income, access to extension service, access to credit, access to climate information and agro-ecological settings were the most important determinant factors that significantly 
affected the choice of farmers to climate change adaptations.

Dirriba and Jema, (2015) investigation on factors Affecting the Choices of Coping Strategies for Climate Extremes: The Case of Yabello District, Borana Zone, Oromia National Regional State, Ethiopia using multinomial logit model revealed that, sex of household head, education status of household head, size of livestock holding, market distance from homestead, access to credit, weather information, and training and agro-pastoral income are significant determinants.

For instance, Feleke et al. (2016) analyzed Determinants of adaptation choices to climate change by sheep and goat farmers in Northern Ethiopia: the case of Southern and Central Tigray, Ethiopia.The result from descriptive statistic, multivariate probit model and Ordinary Least Squares revealed that farmers' choice of adaptation strategies were significantly affected by factors such as access to information, farming experience, distance to nearest market center, income, agro ecological zone and village population number. The study was though instructive, it was restricted to sheep and goat farmers.

Tesfaye and Seifu (2016) analyzed climate change adaptations of smallholder farmers in Southeast Ethiopia.The study employed descriptive statistics and multinomial logit model . The result depicted agronomic practices and use of agricultural inputs have a strong association with education, access to weather information, access to credit and farm income.

Seid et al. (2016) study on perception and adaptation strategy of farmers to climate change stated that sex of the household head, literacy status, farming experience, family size, land holding, to farmer extension, farm income,non-farm income, access to credit, training and media, extension contact,livestock ownership, market distance have a significant impact on climate adaptation choices.

In addition, Belaineh et al. (2013) study also revealed that sex, plot size and frequency of extension contact, family size,offfarm income and training are significantly affects the preference of adaptation strategies.

Summary: Based on above different empirical evidences the determine factors differ from place to place, farmers to farmers .Also adaptation strategy taken by smallholder farmers vary, because it dependence on potential of up taking adjustment methods.

\section{Conclusion and suggestions for future line of work}

The purpose of this paper is to review desk researches on Perception and Adaptation Strategies of Smallholder farmers' to face climate Change in Ethiopia. The seminar depicted that despite Ethiopia followed Agricultural development led industrialization policy, with rain-fed agriculture strategy the efforts made towards reducing climate change impact is too low compared with the observed change of climate. This would be a cause for the countries vulnerablity to current climate variability and change, which will also increase the losses from rain-fed agriculture and increase risk of food insecurity. The review confirmed as the majority of Ethiopian farmers are aware that the temperature and rainfall patterns have changed from time to time. To deal with climate change impacts, smallholder's farmers are being pursued varies adaptation mechanism which includes diversification of crops, adjusting planting and harvesting dates, increased use of irrigation, planting tree crops, increased use of water and soil conservation practices, using improved varieties and diversifying activities from farm to non-farm activities, livestock slaughtering and/or selling them during extended drought periods,fodder preservation, and restocking after the drought,shift to livestock such as camel and goat, and dug more boreholes in drier area.

The review also identifies as much of the research is focused on crop sector,leads to dearth of information regarding livestock sectors.Determining factors of adaptation strategies identified from the review includes:- agro ecology ,gender, age ,farming experience, family size, education, credit access, frequency of extension services, access to information, trainings, and market distance, and engaging in non-farm income are major the factors that determine for adopting different climate change adaptation measures in Ethiopia. Based on the seminar outcome, it has been suggested to further investigate deep rooted researches on livestock sectors adaptation strategies and available indigenous knowledge as adaptation strategies especially in pastoral areas.Further more,there is a need to explore impact of climate change and single adaptation strategies on livelihood of societies at each farm level autonomously.

\section{CONFLICTS OF INTERESTS}

The authors have not declared any conflict of interests.

\section{Acknowledgments}

First and for most, we would like to extend our unshared thanks to the almighty God for providing us the opportunity and smoothening of all aspects regarding the program. next to God, we extend our thanks and appreciation to our advisor Mr. Yadeta Bekele ,Ermias Melaku and Dr. Rijalu Negash for there supportive idea and knowledge they made in our senior seminar work. 


\section{REFERENCES}

Abid, M., Scheffran, J., Schneider, U. A. \& Ashfaq, M. 2015. Farmers' perceptions of and adaptation strategies to climate change and their determinants: The case of Punjab province, Pakistan. Earth System Dynamics, 6, 225-243.

Abrham, B., Recha, J. W., Teshale, W. \& Morton, J. F. 2017. Smallholder farmers ${ }^{\text {ee }}$ adaptation to climate change and determinants of their adaptation decisions in the Central Rift Valley of Ethiopia. Agriculture and Food Security, , 6, 1-13. .

ACCCA 2010. Improving Decision- Making Capacity of Small Holder Farmers in Response to Climate Risk Adaptation in Three Drought-Prone Districts of Tigray, Northern Ethiopia Farm-Level Climate Change Perception and Adaptation in Drought Prone Areas of Tigray, Northern Ethiopia.

Acquah-de Graft, H. \& Onumah, E. 2011. Farmers' perceptions and adaptations to climate change: An estimation of willingness to pay. Agris, , 3, 31-39.

ADB 2015. Climate Change.

Adger, W., Brooks , N., Bentham, G. \& Agnew , M., Eriksen S. 2004. New indicators of vulnerability and adaptive capacity. Tyndall Centre for Climate Change Research Norwich; .

Aemro, T., Jemma, H. \& Mengistu, K. 2012a. Climate change adaptation strategies of smallholder farmers: The case of Babilie District, East Harerghe Zone of Oromia Regional State of Ethiopia. Journal of Economics and Sustainable Development, 3, 1-12.

Aemro, T., Jemma, H. \& Mengistu, K. 2012b. Climate change adaptation strategies of smallholder farmers: The case of Babilie District, East Harerghe Zone of Oromia Regional State of Ethiopia. . Journal of Economics and Sustainable Development, , 3, , 1-12.

AGRA 2014. Africa Agriculture Status Report 2014: Climate Change and Smallholder Agriculture in Sub-Saharan Africa. Nairobi, Kenya.

Aschalew, S. 2014. Smallholder Farmers Adaptation Strategies to Climate Change in Ethiopia: Evidence from Adola Rede Woreda, Oromia Region. Journal of Economics and Sustainable Development, 5, 162-182.

ASFG 2013. A framework for an enabling environment.International NGOs working together with Africa's smallholder farmer, Supporting smallholder farmers in Africa. London.

Asrat, p. \& Simane, B. 2018a. Farmers' perception of climate change and adaptation strategies in the Dabus watershed, North-West Ethiopia Ecological processes, 7.

Asrat, p. \& Simane, B. 2018b. Farmers' perception of climate change and adaptation strategies in the Dabus watershed, North-West Ethiopia journal of Ecological processes, .

Asrat, P. \& Simane, B. 2018c. Farmers'perception of climate change and adaptation strategies in the Dabus watershed,North-West Ethiopia. . Ecological Processes, 7, 1-13. .

Aymone, G. 2009. Understanding farmers' perceptions and adaptation to climate change and variability, The case of the Limpopo basin, South Africa. . International Food Policy Research Institute: . Washington DC.

Baca, M., La "derach, P., Haggar, J., Schroth , G. \& Ovalle , O. 2014. An Integrated Framework for Assessing Vulnerability to Climate Change and Developing Adaptation Strategies for Coffee Growing Families in Mesoamerica. . https://doi.org/10.1371/journal.pone.

Badege, B., Neufeldt, H., Mowo, J., Abdu.A., Muriuki, J., Gemedo, D., Tewodros, A., Guilloze.K., Habtemariam, K., Dawson, L., Luedeling, E. \& Mbow, C. 2013. Farmers' Strategies for Adapting to and Mitigating Climate Variability and Change through Agroforestry in Ethiopia and Kenya. In: CARYN M. DAVIS, B. B., AND ALEKSANDRA DMITRIEV. (ed.). Corvallis, Oregon. : Oregon State University, .

Bedeke, S. B., Vanhove, W., Wordofam, M. G., Natarajan, K. \& Van Damme, P. 2018. Vulnerability to climate change among maize-dependent smallholders in three districts of Ethiopia. climate research.

Belaineh, L., Yared, A. \& Woldeamlak, B. 2013a. Small holder farmers perception and adaptation to climate change variablity and change, in Doba district,west Hararghe,Ethiopia. Asian Journal of Empirical Research journal homepage: http://aessweb.com/journal-detail.php?id=50043.

Belaineh, L., Yared, A. \& Woldeamlak, B. 2013b. Smallholder farmers ${ }^{\text {ee }}$ perceptions and adaptation to climate variability and climate change in Doba District, West Hararghe, Ethiopia. Asian Journal of Empirical Research, 3, 251-265.

Below, T., Artner, A., Siebert, R. \& Sieber, S. 2010. Micro-level Practices to Adapt to Climate Change for African Small-scale Farmers INTERNATIONAL FOOD POLICY RESEARCH INSTITUTE

Bewuketu, M. 2017. Farmers' perception and adaptation strategies to climate change: the case of woreillu district of amhara region, northeastern ethiopia Master of science in agricultural and applied economics

HARAMAYA UNIVERSITY, HARAMAYA.

Bouroncle, C., Imbach, P., Rodrı 'guez-Sa 'nchez, B., Medellı 'n, C. \& Martinez-Valle A, L. d., P. 2017. Mapping climate change adaptive capacity and vulnerability of smallholder agricultural livelihoods in Central America: ranking and descriptive approaches to support adaptation strategies. Climatic Change.

Bryan, E., Deressa, T. T., Gbetibouo, G. A. \& Ringler, C. 2009. Adaptation to climate change in Ethiopia and 
South Africa: Options and constraints. Environmental science and policy 12, 413-426. .

Degefu, W. 1987. Some aspects of meteorological drought in Ethiopia. . Drought and Hunger in Africa. Cambridge: In M. H. Glantz (Ed.), ed.: Cambridge University Press. .

Deressa, T., R.M.Hassan., Tekie, A., Mahmud , Y. \& ., C. R. 2008. Analyzing the determinants of farmers' choice of adaptation methods and perceptions of climate change in the Nile Basin of Ethiopia. Discussion Paper. IFPRI

Dirriba , M. \& Jema, H. 2015. . Factors Affecting the Choices of Coping Strategies for Climate Extremes: The Case of Yabello District, Borana Zone, Oromia National Regional State, Ethiopia. Science Research. Vol. 3, No. 4, 2015, pp. 129-136. doi: 10.11648/j.sr.20150304.11

FAO 2015. The economic lives of smallholder farmers. An analysis based on household data from nine countries. Food and Agriculture Organization of the United Nations. Rome

FAO 2019. Annual report on food and hunger

Feleke, F. B., Berhe, M., Gebru, G. \& Hoag, D. 2016. Determinants of adaptation choices to climate change by sheep and goat farmers in Northern Ethiopia: the case of Southern and Central Tigray, Ethiopia. SpringerPlus, 5:1692

Fikadu, M., Adugn, E. \& Taye, T. 2015. Development agents' perception about the effect of climate risk on livestock productionResearch gate

Fosu-Mensah, B., Vlek, P. \& Manschadi, M. 2010. Farmers' Perceptions and Adaptations to Climate Change: A Case Study of Sekyedumase District in Ghana. . A contributed paper presented at World Food Systems Conference. Tropentag, Zurich:

Fussel, H. M. 2007. Adaptation planning for climate change: concepts, assessment approaches, and key lessons. Sustainability Science 2 (2): , 2, 265-275.

Gebru, H., Kindie, T., Girma, M. \& Belay , K. 2015 Farmers ${ }^{\text {ee }}$ climate change adaptation options and their determinants in Tigray Region, Northern Ethiopia. African Journal of Agricultural Research, , 10, 1 956964. .

Gedefa, M., Girma, A., Denghua, Y., Hao, W. \& Agitew , G. 2018. Farmer's Perceptions and Adaptation Strategies to Climate Change, Its Determinants and Impacts in Ethiopia: Evidence from Qwara District.

Journal of Earth Science \& Climatic Change, 9.

Gedefaw, M., Girma, A., Denghua, Y., Hao, W. \& Agitew, G. 2018. Farmer's Perceptions and Adaptation Strategies to Climate Change, Its Determinants and Impacts in Ethiopia: Evidence from Qwara District Earth Sci Clim Change 2018, 9:7 DOI: 10.4172/2157-7617.1000481.

Gezie, M. 2019. Farmer's response to climate change and variability in Ethiopia: A review Cogent Food \& Agriculture, 5.

Gutu, T., Bezabih , E. \& Mengistu, K. 2012. Econometric analysis of local level perception, adaptation and coping strategies to climate change induced shocks in North Shewa, Ethiopia. International Research Journal of Agricultural Science and Soil Science, 2, 347-363.

Guzzetti, F. 2016. Forecasting natural hazards, performance of scientists, ethics, and the need for transparency. Toxicological \& Environmental Chemistry. , 98, 1043-1059.

IFPRI 2007. The Future of Small Farms for Poverty Reduction and Growth. Discussion Paper.

IPCC 2001. Climate change Impacts, adaptation and vulnerability.

IPCC 2007. Climate change. Contribution of working Groups I, II and III to the fourth assessment report of the intergovernmental Panel on climate change. Geneva, Switzerland.

IPCC 2012. Glossary of terms in managing the risks of extreme events and disasters to advance climate change adaptation. ambridge, UK. New York, NY.USA. .

IPCC

ClimateChange.https://www.ipcc.ch/pdf/assessmentreport/ar5/wg1/WGIAR5_SPM_brochure_en.pdf.

2013.

IPCC 2014. Climate Change Impacts, Adaptation and Vulnerability: Regional Aspects. . Cambridge University Press.

Juana, J., Kahaka, Z. \& Okurut, F. 2013. Farmers' Perceptions and Adaptations to Climate Change in Sub-Sahara Africa: A Synthesis of Empirical Studies and Implications for Public Policy in African Agriculture. Agricultural Science, 5, 121-135.

Komba, C. \& Muchapondw, E. 2015. Adaptation to Climate Change by Smallholder Farmers in Tanzania Environment for Development

Kurukulasuriya, P. \& Mendelson, R. Crop Selection: Adapating to Climate Chnage in Africa. IFPRI. Environment and Production Technology Division., 2006 Washington, DC: . International Food Policy Research Institute.

Lautze, S. Y., Aklilu, A., Raven-Roberts, H., Young, G., Learning., K. a. J. \& 2013. Risk and Vulnerability in Ethiopia: Learning from the Past, Responding to the Present, preparing for the future. Report for the U.S. Agency for International Development,. Addis Ababa, Ethiopia. .

Maddison, D. 2006. The perception and adaptation to climate change in Africa. Centre for Environmental 
Economics and Policy in Africa. Pretoria, South Africa, University of Pretoria.

Mandleni, B. \& Anim, F. 2011. Perceptions of Cattle and Sheep Framers on Climate Change and Adaptations in the Eastern Cape Province of South Africa. . Journal of Human Ecology, 34, 107-112.

Mertz, O., Mbow, C., Reenberg, A. \& Diouf, A. 2009. Fermers' Perceptions of Climate Change and Agricultural Adaptation Strategies in Rural Sahel. Environmental Management,, 43, 804-816. .

NBE 2018. Annual report of 2017-2018.

Nega, D., Mohammed, C., Bridle, K., Corkrey, R. \& McNeil, D. 2015. Perception of climate change and its impact by smallholders in pastoral/agropastoral systems of Borana, South Ethiopia. SpringerPlus, , 4, 236. .

NMA 2006. Climate change national Adaptation Programme of Action (NAPA) of Ethiopia. Addis Ababa Ethiopia. .

NMA 2007. Climate change national Adaptation Programme of Action (NAPA) of Ethiopia. . Addis Ababa Ethiopia.

NMS 2007. Climate Change National Adaptation Program of Action (NAPA) of Ethiopia. NMSA, Addis Ababa. . NMSA 2007. Climate Change National Adaptation Program of Action (NAPA) of Ethiopia. . Addis Ababa.

Phiiri, G. K., Egeru, A. \& Ekwamu, A. 2016. Climate change and agriculture nexus in Sub-Saharan Africa: the agonizing reality for smallholder farmers. International Journal of Current Pharmaceutical Review and Research, 8

Ramamasy, S. \& Baas, S. 2007. Climate variability and change: Adaptation to drought in Bangladesh. Rome,Italy FAO.

Schaffnit-Chatterjee, C. 2014. Agricultural value chains in Sub-Saharan Africa: From a development challenge to a business opportunity. Deutsche Bank AG. Available from: .

Seid, S., Jema.H. \& Degye, G. 2016. Climate Change Adaptation Strategies of Smallholder Farmers: The Case of Assosa District, Western Ethiopia. Environment and Earth Science: , 6, 103-109.

Seid, S. \& Tamiru, C. 2015. Farmers' Perception, Impact and Adaptation Strategies to Climate Change among Smallholder Farmers in Sub-Saharan Africa: A Systematic Review

Resources Development and Management 26.

Seid, S. \& Tamiru, C. 2016 Farmers' Perception, Impact and Adaptation Strategies to Climate Change among Smallholder Farmers in Sub-Saharan Africa: A Systematic Review

Journal of Resources Development and Management 26.

Sherbinin, A., Caffrey , P. \& Farmer, A. 2014. Spatial Climate Change Vulnerability Assessments: A review of data, methods, and issues,African and Latin American Resilience to Climate Change Project. USAID. Prosperity, Livelihoods, and Conserving Ecosystems (PLACE). Tetra Tech ARD.

Solomon, A., Getachew, F., Birhanu, G. \& Yemane, A. 2016. Perception and adaptation models of climate change by the rural people of lake Tana Sub-Basin, Ethiopia. Environmental Systems Research, 5.

Temsgen, G. 2014. Climate Change Adaptation and Mitigation Measures in Ethiopia. . Journal of Biology, Agriculture and Healthcare

Tesfaye, W. \& Seifu, L. 2016. Climate change perception and choice of adaptation strategies: empirical evidence from small holder farmers in east EthiopiaInt.J.Clim.ChangeStrateg.Manage. 8253-70

Tesfahunegn, F., Gebreyesus, B., Kirubel, M. \& Abadi, T. 2016. Farmer's perception on causes, indicators and determinants of climate change in Northern Ethiopia: Implication for developing adaptation strategies. Applied Geography 73: 1-12.

UNDP 2007. Fighting climate change: Human solidarity in a divided world. New York. .

UNFCCC 2011. Climate Change: Impacts, Vulnerabilities and Adaptation in Developing Countries.

Van den Ban, A. W. \& Hawkins, H. S. 2000. Agricultural Extension,. 2nd edition. ed. Blackwell Science, UK. .

WB 2006. Ethiopia Managing water resources to maximize sustainable growth. Country water resources assistance Strategy, . Washington DC. World Bank.

WBG 2010. Economics of adaptation to climate change, Ethiopia country study.

Weldleul, A. L. 2016. Analysis of Smallholder Farmers' Perceptions of Climate Change and Adaptation Strategies to Climate Change: The Case of Western Amhara Region, Ethiopia Doctor of Philosophy in Environmental Management Ph.d, UNIVERISTY OF SOUTH AFRICA.

Weldlul, A. L. 2016. Analysis of Smallholder Farmers' Perceptions of Climate Change and Adaptation Strategies to Climate Change: The Case of Western Amhara Region, Ethiopia Phd, Univeristy of south africa

Wondimagegn, T. \& Lemma, S. 2016. Climate change perception and choice of adaptation strategies: Empirical evidence from smallholder farmers in east Ethiopia. International Journal of Climate Change Strategies and Managemen, 8, 253-270. .

WWF 2015. Climate Change

Yirga, C. 2007. The dynamics of soil degradation and incentives for optimal Management in Central Highlands of Ethiopia. $\mathrm{PhD}$ thesis, University of Pretoria. 